\title{
Effect of Nitrogen Management Practices on the Productivity of Late Sown Wheat (Triticum aestivum L.) Varieties
}

\author{
Shiv Vendra Singh ${ }^{1}$, Avanish Kumar Singh ${ }^{2}$, Nikhil Raghuvanshi ${ }^{1}$ and R.A. Singh ${ }^{1}$ \\ ${ }^{1}$ Department of Agronomy, Narendra Dev University of Agriculture and Technology, \\ Faizabad (U.P), India \\ ${ }^{2}$ ICAR-Agricultural Technology Application Research Institute, Kanpur (U.P), India \\ *Corresponding author
}

\section{Keywords}

Wheat,

Triticum aestivum $\mathrm{L}$.

Wheat varieties,

Nitrogen

Management

Practices.

Article Info

Accepted:

14 June 2017

Available Online:

10 July 2017

\section{A B S T R A C T}

A field experiment was carried out at Agronomy Research Farm of Narendra Deva University of Agriculture and Technology, Narendra Nagar (Kumarganj), Faizabad (U.P.) during Rabi season of 2014-15 to study the response of late sown wheat varieties to different nitrogen management practices. Twenty treatment consisted of five doses of nitrogen $\left(90 \mathrm{~kg} \mathrm{~N}^{-1}, 120 \mathrm{~kg} \mathrm{~N} \mathrm{ha}^{-1}, 90 \mathrm{~kg} \mathrm{~N}^{-1}+25 \% \mathrm{~N}\right.$ through FYM, $120 \mathrm{~kg} \mathrm{~N}^{-1}{ }^{-1}$ $+25 \% \mathrm{~N}$ through FYM, $150 \mathrm{~kg} \mathrm{~N} \mathrm{ha}^{-1}$ ) and four varieties of wheat (HD-2643, HUW-234, PBW-373 and HD-2285).The experiment was conducted in Randomized Block Design (R.B.D.) factorial with three replications on silt loam having low organic carbon $(0.38 \%)$, nitrogen $\left(204 \mathrm{~kg} \mathrm{ha}^{-1}\right)$, medium in phosphorus $\left(15.35 \mathrm{~kg} \mathrm{ha}^{-1}\right)$ and potassium $\left(267 \mathrm{~kg} \mathrm{ha}^{-1}\right)$. The growth characters like plant height, dry matter accumulation, number of tillers, leaf area index were significantly higher under $150 \mathrm{~kg} \mathrm{~N}^{-1}$ being at par with120 $\mathrm{kg} \mathrm{N} \mathrm{ha}^{-1}+$ $25 \% \mathrm{~N}$ through FYM over rest of the levels and among the varieties PBW- 373 was at par with HD-2285 while significantly superior over HP-2643 and HUW-234. The yield components like number of ears per meter row length, ear length $(\mathrm{cm})$, number of grain ear $^{-1}$, grain weight ear ${ }^{-1}(\mathrm{~g})$ grain yield $\left(\mathrm{kg} \mathrm{ha}^{-1}\right)$, straw yield $\left(\mathrm{kg} \mathrm{ha}^{-1}\right)$ and nitrogen uptake at harvest $\left(\mathrm{kg} \mathrm{ha}^{-1}\right)$ were maximum under $150 \mathrm{~kg} \mathrm{~N} \mathrm{ha}^{-1}$ which was at par with $120 \mathrm{~kg} \mathrm{~N}$ $\mathrm{ha}^{-1}+25 \% \mathrm{~N}$ through FYM and among the varieties PBW-373 being at par with HD-2285 with respect to the yield components while grain yield $\left(\mathrm{kg} \mathrm{ha}^{-1}\right)$ and straw yield $\left(\mathrm{kg} \mathrm{ha}^{-1}\right)$ was maximum under PBW-373 followed by HD-2285. Harvest index and 1000-grain weight $(\mathrm{g})$ were not influenced significantly due to nitrogen management practices and varieties. Thus it may be concluded that nitrogen management practice of $150 \mathrm{~kg} \mathrm{~N} \mathrm{ha}^{-1}$ proved as the most suitable practice for exploitation of the yield potential of late sown wheat. Among the varieties PBW-373 and HD-2285 were found most suitable for cultivation under late sown condition for achieving higher yield and economics.

\section{Introduction}

Wheat (Triticum aestivum L.) is a staple food of the world and falls under Poaceae family. It is primarily grown in temperate regions and also at higher altitude under tropical climatic areas in winter season. It is the single most important cereal crop that has been considered as integral component of the food security system of the several nations. It ranks first in the world among the cereals both in respect of area (225.43 mha) and production (696.94 mt.). In India, total area under wheat is 29.90 mha with the production and 
productivity of $93.90 \mathrm{mt}$ and $3140 \mathrm{~kg} \mathrm{ha}^{-1}$, respectively (Anonymous, 2013).

Major wheat producing countries in the world are China, India, USA, France, Russia, Canada, Australia, Pakistan, Turkey, UK, Argentina, Iran and Italy. These countries contribute about $74.82 \%$ of the total world wheat production. As far as India is concerned, about $90 \%$ of the total wheat production is contributed by northern states. Among them, Uttar Pradesh ranks first with respect to area (9.734 mha) and production $(30.30 \mathrm{mt})$ but the productivity is much lower $\left(3113 \mathrm{~kg} \mathrm{ha}^{-1}\right)$ than Punjab (5097 kg ha ${ }^{-1}$ ) and Haryana (5182 $\mathrm{kg} \mathrm{ha}^{-1}$ ) (Anonymous, 2013).

The demand of wheat by 2020 has been projected to be between 105 to $109 \mathrm{mt}$ in the country. Most of the increase in production will have to manage from integrated use of resources, as the land area under wheat is not expected to expand further. The productivity of wheat in eastern U.P. is very low $(2500 \mathrm{~kg}$ $\mathrm{ha}^{-1}$ ), might be due to adoption of cerealcereal (Rice-Wheat) cropping system, late sowing, poor weed management and imbalance fertilization, etc.

The late transplanting of rice or use of long duration varieties of rice in low land delays the sowing of wheat from mid November to December. The preceding crops such as sugarcane, potato, toria etc. and other factors forced to sow the wheat as late as in the month of December and January. Due to delay sowing wheat yield is declined drastically. Low temperature, poor mineral accumulation, less translocation of photosynthates from source to sink, hot desiccating wind during milking stage forced premature drying, unsuitable location specific varieties, imbalanced nutrient management are responsible for low yield under late sown wheat. Different varieties under late sown condition respond variably to various nitrogen management practices.
Balanced fertilizer through organic and inorganic sources improves the soil health as well as boosts the productivity of wheat. Organic matter is the substrate for a large number of soil living beneficial organisms which are essential to keep the plant healthy. All India Co-ordinate Research Project on microbial development reported that organic manure can be enriched by Aspergillus awamori. Application of 5 tonnes of same enriched compost under rice - wheat sequence gave adequate phosphate, comparable to the application of $40 \mathrm{~kg}$ Missouri rock phosphate. Enriched FYM improves the nutrient availability and increases wheat yield. Organic matter in soil increases the water holding capacity, cation exchange capacity as well as improves the soil structure for better performance of microorganisms. The soil which enriched in organic matter has been found to respond better to the application of nitrogenous fertilizers (Subbiah and Bajaj, 1968). About $40 \%$ of cattle dung is available for manuring, rest being wasted or used as fuel (Whyte, 1957). Thus, a good amount of organic waste is lost which is an important input for agricultural production. In the event of widespread energy crisis and deterioration of soil fertility due to intensive agriculture and imbalance use of fertilizers, it is highly desirable for making massive efforts to adopt organic matter recycling as a source of bioenergy and to supplement the demand gap of $\mathrm{N}, \mathrm{P}, \mathrm{K}$ as well as to enrich the soil in respect to micronutrients.

Thus, the combination of FYM with inorganic fertilizers may be highly effective for increasing the yield under late sown wheat as well as better quality of produce in addition to sustaining biological health and maintaining balanced $\mathrm{C}$ : $\mathrm{N}$ ratio of the soil. The information on nutrient management under late sown wheat is very meager and fragmentary. Keeping these facts in view, the 
present investigation entitled "Effect of nitrogen management practices on the productivity of late sown wheat (Triticum aestivum L.) varieties" was under taken at Agronomy Research Farm, Narendra Deva University of Agriculture and Technology, Narendra Nagar, Kumarganj, Faizabad (U.P.) during Rabi season of 2014-2015 to achieve the following objectives;

$>\quad$ To find out the suitable nitrogen management practice for late sown wheat,

To assess the performance of wheat varieties under various nitrogen levels.

\section{Materials and Methods}

The field experiment was conducted at Agronomy Research Farm, Narendra Deva University of Agriculture and Technology, Narendra Nagar (Kumarganj) Faizabad (U.P.), during Rabi season of 2014-15. The experimental site falls under sub-tropical zone in Indo-gangatic plains and lies between $26^{0} .47$ North latitude, $82^{0} .12$ East longitudes, at an attitude of about 113.0 meter from mean sea level. The soil of experimental field was low in available nitrogen $(204.00 \mathrm{~kg} / \mathrm{ha})$ and organic carbon $(0.34 \%)$, medium in available phosphorus (15.35 kg/ha) and high in potassium $(267.00 \mathrm{~kg} / \mathrm{ha})$. The reaction of the soil was slightly alkaline. The total rainfall during course of experimentation was 124.0 $\mathrm{mm}$. During the crop season, the lowest temperature $\left(5.9^{0} \mathrm{C}\right)$ was recorded in the month of December to January and the maximum $\left(36.8^{\circ} \mathrm{C}\right)$ in the month of April. The highest mean relative humidity $(86.6 \%)$ was recorded in the month of January. The experiment was laid out in randomized block design with four varieties (HD-2639, HUW234, PBW-373 and HD-2285) and five nitrogen management practices $\left(90 \mathrm{~kg} \mathrm{~N} \mathrm{ha}^{-1}\right.$, $120 \mathrm{~kg} \mathrm{~N} \mathrm{ha}^{-1}, 90 \mathrm{~kg} \mathrm{~N}^{-1}+25 \% \mathrm{~N}$ through FYM, $120 \mathrm{~kg} \mathrm{~N}^{-1}+25 \% \mathrm{~N}$ through FYM, $150 \mathrm{~kg} \mathrm{~N} \mathrm{ha}^{-1}$ ) with three replication. There were twenty treatment combinations comprised of 4 varieties and 5 nitrogen management practices. The sowing was done on 15 December 2014 with the seed rate of $125 \mathrm{~kg} \mathrm{ha}^{-1}$ and spacing between rows was 20 $\mathrm{cm}$ apart. The nitrogen as per treatment through FYM was applied 15 days before sowing, while rest of the nitrogen was applied through Urea and DAP (18\% $\mathrm{N}$ and $46 \%$ $\mathrm{P}_{2} \mathrm{O}_{5}$ ). Half of the Urea was applied as basal (at time of sowing) and remaining half dose of nitrogen was applied at 30 days after sowing through the Urea. However, $60 \mathrm{~kg}$ $\mathrm{P}_{2} \mathrm{O}_{5}$ ha $^{-1}$ through DAP and $40 \mathrm{~kg} \mathrm{~K}_{2} \mathrm{O}$ ha $^{-1}$ through muriate of potash was applied at the time of sowing as a basal dose. Five irrigations were given, coinciding with the critical stage of the plant growth, beside presowing irrigation by Tube-well. In order to check the weeds growth one manual weeding was done at 35 days after sowing. The crop was harvested at proper stage of maturity as determined by visual observations on 25 April 2015.

Half meter length on either end of each plot and 2 border rows from each side (border rows) were first removed from the field to avoid error. The crop in net plot was harvested for calculation of yield data. Produce was tied in bundles and weighted for biomass yield. Threshing of produce of each net plot was done by using pull man's thresher. Five plants selected randomly were tagged from the net plot area of each treatment for recording various biometric observations and the data collected were analyzed statistically following the procedure described by Gomez and Gomez (1984).

\section{Results and Discussion}

\section{Growth characters}

\section{Plant height (cm)}

Plant height increased progressively at the successive stages of crop growth as 
influenced by various varieties and nitrogen management practices. Data pertaining to plant height is summarized in table 1. In general, plant height increased successfully at 30, 60 and 90 DAS. There after the rate of increase in plant height was nominal at harvest stage of the crop. Maximum plant height was recorded with variety PBW-373, which was at par with HD-2285 and significantly superior over HD-2643 and HUW-234 varieties. Same trend as 60DAS was found at 90 days after sowing and at harvest stage. Regarding nitrogen management practices, plant height as increased significantly with increasing levels of nitrogen from $90 \mathrm{~kg} \mathrm{~N} \mathrm{ha}^{-1}$ to $150 \mathrm{~kg} \mathrm{~N} \mathrm{ha}^{-1}$. Application of $150 \mathrm{~kg} \mathrm{~N}^{-1}$ was found at par with $120 \mathrm{~kg} \mathrm{~N} \mathrm{ha}^{-1}+25 \% \mathrm{~N}$ through FYM and $120 \mathrm{~kg} \mathrm{~N} \mathrm{ha}^{-1}$ and it was found significantly superior with respect to the plant height over rest of the nitrogen management practices at 30 days after sowing. Same trend was found at 60 and 90 DAS whereas at harvest stage, it was at par only $120 \mathrm{~kg} \mathrm{~N}^{-1}$ $+25 \% \mathrm{~N}$ through FYM and significantly superior over all other nitrogen management practices. Variation in plant height among varieties might also be probably due to their genetic characters. Similar finding in respect to varieties were reported by Brijkishor (1998). The significant increase in plant height was recorded in present investigation, which was mainly due to more availability of nitrogen (Table 1). Higher nitrogen level resulted higher nitrogen uptake, which ultimately results into increased protein synthesis, cell division and cell enlargement which express morphologically an increase in height of plant. Similar findings were reported by Mankotia et al., (2007).

\section{Number of tillers $\mathrm{m}^{-1}$ row length}

The number of tillers $\mathrm{m}^{-1}$ row length increased progressively at the successive stages of crop growth as influenced by various varieties and nitrogen management practices. Data pertaining to number of tillers $\mathrm{m}^{-1}$ have been summarized in table 2. In general, number of tiller increased progressively up to 90 DAS stage. There after the rate of increase in number of tillers decreased at harvest stage of the crop. Maximum number of tillers was found at 90 days after sowing and thereafter, decreased till the maturity. The higher number of tillers $\mathrm{m}^{-1}$ row length were recorded with variety $\mathrm{PBW}-373$, which was at par with variety HD-2285 and significantly superior over all other varieties. Same trend was found at 60, 90 DAS and at harvest stage. Number of tillers was significantly affected by various nitrogen management practices at all the stages of crop growth. Regarding nitrogen management practices, number of tillers increased significantly with increasing levels of nitrogen. Application of $150 \mathrm{~kg} \mathrm{~N} \mathrm{ha}^{-1}$ was found at par with $120 \mathrm{~kg} \mathrm{~N}^{-1}+25 \% \mathrm{~N}$ through FYM and $120 \mathrm{~kg} \mathrm{~N} \mathrm{ha}$ and significantly superior over rest of the nitrogen levels at 30 DAS, while at 60, 90 DAS and harvest stage it was only at par with $120 \mathrm{~kg} \mathrm{~N}$ $\mathrm{ha}^{-1}+25 \% \mathrm{~N}$ through FYM and significantly superior over all other nitrogen management practices. Variation in number of tillers might be due to their own genetic characteristics. Similar finding in respect to varieties were reported by Behra (1994) and Singh (1998). The number of tillers per meter row length at 30, 60, 90 days after sowing and at harvest stage and effective tillers were influenced significantly by nitrogen management practices (Table 2). The significant increase in number of tillers per meter row length was recorded only upto $150 \mathrm{~kg} \mathrm{~N}$. Similar results were reported by Gontia and Joshi (2000), Avijit et al., (2003) and Ram and M.I.R. (2006).

\section{Dry matter accumulation $\left(g \mathrm{~m}^{-1}\right.$ row length)}

Dry matter accumulation was affected considerably due to various varieties and nitrogen management practices. Data 
pertaining to number of tillers have been summarized in table 3 . The table revealed that dry matter accumulation was significantly influenced by various varieties and nitrogen management practices. In general, the dry matter accumulation increased with advancement in crop growth stages. A perusal of data in table revealed that maximum dry matter accumulation was recorded with variety PBW-373 which was at par with HD2285 and significantly superior to rest of the varieties at 30,60, 90 DAS and at harvest stage. Regarding nitrogen management practices, dry matter accumulation was influenced significantly. Maximum dry matter accumulation was recorded with the application of $150 \mathrm{~kg} \mathrm{~N} \mathrm{ha}^{-1}$ which was found at par with $120 \mathrm{~kg} \mathrm{~N} \mathrm{ha}{ }^{-1}+25 \% \mathrm{~N}$ through FYM and significantly superior over all other nitrogen levels at all stages of crop growth.

Significant dry matter accumulation by plants was because of more number of tillers per meter row length. Healthy shoots due to higher nutrients absorption capacity, more number of ear bearing tillers due to less mortality resulted higher dry matter production. Minimum dry matter accumulation (167.01 $\mathrm{g} \mathrm{m}^{-1}$ row length) recorded with variety HUW-234 at harvest stage. However, which reflected due to less number of ears bearing tillers $\mathrm{m}^{-1}$ row length resulted less dry matter production. Similar findings were reported by Singh (1998). The Dry matter accumulation influenced significantly due to different nitrogen management practices at all the stages (Table 3). Significant dry matter accumulation recorded upto150 $\mathrm{kg} \mathrm{N}$. This might be attributed due to more synthesis of food material in plants. Similar findings were reported by Singh (1991).

\section{Yield contributing characters}

The data pertaining to yield attributing characters viz., number of ear $\mathrm{m}^{-1}$ row length, ear length, number of grains ear ${ }^{-1}$, grain weight ear $^{-1}$ and 1000-grain weight have been presented in table 4 .

\section{Number of ear $\mathrm{m}^{-1}$ row length}

The data presented in table 4 revealed that number of ear per meter row length was significantly influenced by varieties and nitrogen management practices. Maximum numbers of spikes per meter row length were recorded in variety PBW-373 which found was at par with HD-2285 and significantly superior over all other varieties. Regarding nitrogen management practices, application of $150 \mathrm{~kg} \mathrm{~N} \mathrm{ha}{ }^{-1}$ produced maximum number of ear per meter row length which was at par with $120 \mathrm{~kg} \mathrm{~N}^{-1}+25 \% \mathrm{~N}$ through FYM and significantly superior over all other of nitrogen management practices.

\section{Length of ear $(\mathrm{cm})$}

The length of ear influenced significantly by varieties and nitrogen management practices. The maximum length of ear was recorded with variety PBW-373, which was at par with variety HD-2285 and significantly superior over rest of the varieties. As regards nitrogen management practices, maximum ear length was recorded with $150 \mathrm{~kg} \mathrm{~N}^{-1}$ which was at par with $120 \mathrm{~kg} \mathrm{~N} \mathrm{ha}^{-1}+25 \% \mathrm{~N}$ through FYM. However, it was significantly superior over rest of the nitrogen management practices.

\section{Number of grains ear ${ }^{-1}$}

The number of grains ear $^{-1}$ influenced significantly by varieties and nitrogen management practices. The maximum number of grains ear ${ }^{-1}$ was found with variety PBW373, which was at par with variety HD-2285 and significantly superior over all other varieties. Application of $150 \mathrm{~kg} \mathrm{~N} \mathrm{ha}{ }^{-1}$ produced significantly higher number of grains ear ${ }^{-1}$ which was at par with $120 \mathrm{~kg} \mathrm{~N}$ 
ha $^{-1}+25 \% \mathrm{~N}$ through FYM and significantly superior over other nitrogen management practices.

\section{Grain weight ear ${ }^{-1}$}

Grain weight ear ${ }^{-1}$ influenced significantly by varieties and nitrogen management practices. The maximum grain weight ear $^{-1}$ was found with variety PBW-373, which was at par with variety HD-2285 and significantly superior over all other varieties. Application of $150 \mathrm{~kg}$ $\mathrm{N}$ ha $^{-1}$ produced significantly higher grain weight ear $^{-1}$ which was at par with $120 \mathrm{~kg} \mathrm{~N}$ $\mathrm{ha}^{-1}+25 \% \mathrm{~N}$ through FYM and significantly superior over all other nitrogen management practices.

\section{0-grain weight $(g)$}

Data pertaining to 1000 -grain weight have been presented in table 4 . The data revealed that the 1000-grain weight (g) was not influenced significantly by varieties as well as nitrogen management practices. Different cultivars tested during experimentation could not reach to the level of significance in increasing the test weight. However, the higher value of test weight (39.28) was obtained with the PBW373. However, the higher test weight of $40.10 \mathrm{~g}$ was recorded with the application of $150 \mathrm{~kg} \mathrm{~N} \mathrm{ha}^{-1}$.

Yield was the resultant of co-ordination of yield attributes. Vigorously growing plants are able to absorb larger quantity of mineral nutrients through well developed root system. The variety PBW-373 gave higher number of ears $\mathrm{m}^{-1}$ row length, grain ear ${ }^{-1}$, length of ear and 1000 grain weight than other varieties (Table 4). It might be due to the genetic character of the variety like more reproductive tillers producing capacity, more ear length etc. Minimum yield contributing characters were credited recorded to HUW-
234. It was due to less reproductive tillers, less ear length as well as less number of grain ear $^{-1}$. Similar findings were reported by Singh and Singh (1989), Singh and Singh (1991), Brijkishor (1998) and Liaquat et al., (2003). The yield contributing characters viz. number of effective tillers, ear length, number of grains ear ${ }^{-1}$, grain weight ear $^{-1}$, test weight (1000-grain weight) increased with increase in nitrogen levels. The significant increase of these characters obtained only upto $150 \mathrm{~kg} \mathrm{~N}$ (Table 4). This might be due to enhanced tillering, photosynthetic area and increased sink size in presence of adequate nitrogen. Similar research findings were reported by Kumpawat and Rathore (2003), Singh (2002) and Parihar (2004).

\section{Yield}

\section{Grain yield $\left(\mathbf{q ~ h a}^{-1}\right)$}

The data pertaining to grain yield were recorded and presented in table 5. The data revealed that the grain yield influenced significantly by varieties as well as nitrogen management practices. Among the varieties, maximum grain yield was recorded with variety PBW-373, which was significantly superior over all other varieties. Increased in grain yield was recorded upto the application of $150 \mathrm{~kg} \mathrm{~N} \mathrm{ha}^{-1}$ but it was not increasing significantly.

Application of $150 \mathrm{~kg} \mathrm{~N} \mathrm{ha}^{-1}$ recorded higher grain yield which was at par with $120 \mathrm{~kg} \mathrm{~N} \mathrm{ha}$ ${ }^{1}+25 \% \mathrm{~N}$ through FYM and $120 \mathrm{~kg} \mathrm{~N} \mathrm{ha}$ and significantly superior over all other nitrogen management practices. The grain yield significantly increased only up to $150 \mathrm{~kg}$ $\mathrm{N} \mathrm{ha}^{-1}$ (Table 5). This might be due to more ear length, number of grains ear ${ }^{-1}$, grain weight ear $^{-1}$ and 1000 grain weight. Similar findings were reported by Singh et al., (2003). 
Table.1 Effect of different treatments on plant height at various growth stages of the wheat crop

\begin{tabular}{|c|c|c|c|c|}
\hline \multirow[t]{2}{*}{ Treatments } & \multicolumn{4}{|c|}{ Plant height $(\mathrm{cm})$} \\
\hline & $30 \mathrm{DAS}$ & $60 \mathrm{DAS}$ & 90 DAS & At harvest \\
\hline \multicolumn{5}{|l|}{ (A) Varieties } \\
\hline HD-2643 & 19.28 & 55.18 & 76.14 & 77.40 \\
\hline HUW-234 & 18.84 & 53.48 & 73.81 & 75.05 \\
\hline PBW-373 & 20.37 & 59.12 & 81.59 & 82.97 \\
\hline HD-2285 & 19.91 & 57.42 & 79.26 & 80.58 \\
\hline SEm \pm & 0.34 & 1.10 & 1.50 & 1.37 \\
\hline $\mathrm{CD}(\mathrm{P}=0.05)$ & 0.98 & 3.14 & 4.79 & 3.93 \\
\hline \multicolumn{5}{|c|}{ (B) Nitrogen management practices } \\
\hline $90 \mathrm{~kg} \mathrm{~N} \mathrm{ha}^{-1}$ & 18.52 & 52.36 & 72.26 & 73.49 \\
\hline $120 \mathrm{~kg} \mathrm{~N} \mathrm{ha}^{-1}$ & 19.75 & 56.86 & 78.47 & 79.76 \\
\hline $\begin{array}{l}90 \mathrm{~kg} \mathrm{~N} \mathrm{ha} \mathrm{ha}^{-1}+25 \% \mathrm{~N} \\
\text { through FYM }\end{array}$ & 18.98 & 54.05 & 74.58 & 75.83 \\
\hline $\begin{array}{l}120 \mathrm{~kg} \mathrm{~N} \mathrm{ha}{ }^{-1}+25 \% \mathrm{~N} \\
\text { through FYM }\end{array}$ & 20.06 & 57.99 & 80.03 & 81.37 \\
\hline $150 \mathrm{~kg} \mathrm{~N} \mathrm{ha}^{-1}$ & 20.68 & 60.24 & 83.15 & 85.55 \\
\hline SEm \pm & 0.38 & 1.23 & 1.67 & 1.53 \\
\hline $\mathrm{CD}(\mathrm{P}=0.05)$ & 1.10 & 3.51 & 4.79 & 4.39 \\
\hline
\end{tabular}

Table.2 Effect of different treatments on number of tillers at various growth stages of the wheat crop

\begin{tabular}{|c|c|c|c|c|}
\hline \multirow[t]{2}{*}{ Treatments } & \multicolumn{4}{|c|}{ Number of tillers $\mathrm{m}^{-1}$ row length } \\
\hline & $30 \mathrm{DAS}$ & $60 \mathrm{DAS}$ & 90 DAS & At harvest \\
\hline \multicolumn{5}{|l|}{ (A) Varieties } \\
\hline HD-2643 & 58.91 & 87.22 & 95.25 & 94.09 \\
\hline HUW-234 & 57.10 & 84.54 & 92.34 & 91.20 \\
\hline PBW-373 & 63.09 & 93.45 & 102.11 & 100.81 \\
\hline HD-2285 & 61.30 & 90.78 & 99.14 & 97.90 \\
\hline SEm \pm & 1.20 & 1.60 & 1.82 & 1.67 \\
\hline $\mathrm{CD}(\mathrm{P}=0.05)$ & 3.42 & 4.59 & 5.22 & 4.79 \\
\hline \multicolumn{5}{|l|}{ (B) Nitrogen management practices } \\
\hline $90 \mathrm{~kg} \mathrm{~N} \mathrm{ha}^{-1}$ & 55.89 & 82.77 & 90.33 & 89.27 \\
\hline $120 \mathrm{~kg} \mathrm{~N} \mathrm{ha}^{-1}$ & 60.70 & 89.87 & 98.17 & 96.96 \\
\hline $\begin{array}{l}90 \mathrm{~kg} \mathrm{~N} \mathrm{ha}{ }^{-1}+25 \% \mathrm{~N} \text { through } \\
\text { FYM }\end{array}$ & 57.72 & 85.45 & 93.32 & 92.17 \\
\hline $\begin{array}{l}120 \mathrm{~kg} \mathrm{~N} \mathrm{ha}{ }^{-1}+25 \% \mathrm{~N} \text { through } \\
\text { FYM }\end{array}$ & 61.89 & 91.67 & 100.11 & 98.87 \\
\hline $150 \mathrm{~kg} \mathrm{~N} \mathrm{ha}^{-1}$ & 63.29 & 95.23 & 104.01 & 102.73 \\
\hline SEm \pm & 1.34 & 1.79 & 2.04 & 1.87 \\
\hline $\mathrm{CD}(\mathrm{P}=0.05)$ & 3.83 & 5.13 & 5.83 & 5.35 \\
\hline
\end{tabular}


Table.3 Effect of different treatments on dry matter accumulation at various growth stages of the wheat crop

\begin{tabular}{|c|c|c|c|c|}
\hline \multirow[t]{2}{*}{ Treatments } & \multicolumn{4}{|c|}{ Dry matter accumulation ( $\mathrm{g} \mathrm{m}^{-1}$ row length) } \\
\hline & $30 \mathrm{DAS}$ & $60 \mathrm{DAS}$ & $90 \mathrm{DAS}$ & At harvest \\
\hline \multicolumn{5}{|l|}{ (A) Varieties } \\
\hline HD-2643 & 14.02 & 108.29 & 172.28 & 211.22 \\
\hline HUW-234 & 13.59 & 104.96 & 167.01 & 204.64 \\
\hline PBW-373 & 15.02 & 116.04 & 184.61 & 226.30 \\
\hline HD-2285 & 14.58 & 112.71 & 179.31 & 219.83 \\
\hline SEm \pm & 0.21 & 2.06 & 3.12 & 3.69 \\
\hline $\mathrm{CD}(\mathrm{P}=0.05)$ & 0.61 & 5.90 & 8.95 & 10.57 \\
\hline \multicolumn{5}{|c|}{ (B) Nitrogen management practices } \\
\hline $90 \mathrm{~kg} \mathrm{~N} \mathrm{ha}^{-1}$ & 13.29 & 102.75 & 163.49 & 200.42 \\
\hline $120 \mathrm{~kg} \mathrm{~N} \mathrm{ha}^{-1}$ & 14.42 & 111.61 & 177.57 & 217.65 \\
\hline $\begin{array}{l}90 \mathrm{~kg} \mathrm{~N} \mathrm{ha}^{-1}+25 \% \mathrm{~N} \text { through } \\
\text { FYM }\end{array}$ & 13.73 & 106.08 & 168.74 & 206.88 \\
\hline $\begin{array}{l}120 \mathrm{~kg} \mathrm{~N} \mathrm{ha-1}+25 \% \mathrm{~N} \\
\text { through FYM }\end{array}$ & 14.74 & 113.83 & 181.08 & 221.97 \\
\hline $150 \mathrm{~kg} \mathrm{~N} \mathrm{ha}^{-1}$ & 15.32 & 118.24 & 188.12 & 230.58 \\
\hline SEm \pm & 0.24 & 2.30 & 3.49 & 4.13 \\
\hline $\mathrm{CD}(\mathrm{P}=0.05)$ & 0.68 & 6.60 & 10.00 & 11.82 \\
\hline
\end{tabular}

Table.4 Effect of different treatments on yield contributing characters of wheat crop

\begin{tabular}{|c|c|c|c|c|c|}
\hline Treatments & $\begin{array}{l}\text { Number of } \\
\text { ears } \mathrm{m}^{-1} \text { row } \\
\text { length }\end{array}$ & $\begin{array}{l}\text { Ear length } \\
\quad(\mathrm{cm})\end{array}$ & $\begin{array}{l}\text { Number of } \\
\text { grains ear }^{-1}\end{array}$ & $\begin{array}{c}\text { Grain } \\
\text { weight ear }^{-1} \\
\text { (g) }\end{array}$ & $\begin{array}{c}\text { Test weight } \\
\text { (1000-grain } \\
\text { weight) }\end{array}$ \\
\hline \multicolumn{6}{|l|}{ (A) Varieties } \\
\hline HD-2643 & 63.92 & 9.02 & 37.72 & 1.48 & 39.12 \\
\hline HUW-234 & 61.93 & 8.73 & 36.59 & 1.44 & 39.17 \\
\hline PBW-373 & 68.45 & 9.67 & 40.42 & 1.59 & 39.28 \\
\hline HD-2285 & 66.49 & 9.38 & 39.27 & 1.54 & 39.23 \\
\hline SEm \pm & 0.87 & 0.12 & 0.59 & 0.02 & 0.70 \\
\hline $\mathrm{CD}(\mathrm{P}=0.05)$ & 2.48 & 0.34 & 1.68 & 0.06 & NS \\
\hline \multicolumn{6}{|c|}{ (B) Nitrogen management practices } \\
\hline $90 \mathrm{~kg} \mathrm{~N} \mathrm{ha}^{-1}$ & 60.64 & 8.54 & 35.83 & 1.35 & 38.53 \\
\hline $120 \mathrm{~kg} \mathrm{~N} \mathrm{ha}^{-1}$ & 65.84 & 9.29 & 38.87 & 1.54 & 39.68 \\
\hline $\begin{array}{l}90 \mathrm{~kg} \mathrm{~N} \mathrm{ha}{ }^{-1}+25 \% \mathrm{~N} \\
\text { through FYM }\end{array}$ & 62.58 & 8.83 & 36.94 & 1.41 & 38.61 \\
\hline $\begin{array}{l}120 \mathrm{~kg} \mathrm{~N} \mathrm{ha}{ }^{-1}+25 \% \mathrm{~N} \\
\text { through FYM }\end{array}$ & 67.16 & 9.48 & 39.66 & 1.59 & 40.05 \\
\hline $150 \mathrm{~kg} \mathrm{~N} \mathrm{ha}^{-1}$ & 69.78 & 9.86 & 41.21 & 1.66 & 40.10 \\
\hline SEm \pm & 0.97 & 0.13 & 0.66 & 0.02 & 0.78 \\
\hline $\mathrm{CD}(\mathrm{P}=0.05)$ & 2.78 & 0.38 & 1.88 & 0.07 & NS \\
\hline
\end{tabular}


Table.5 Effect of different treatments on grain yield, straw yield and harvest index of the wheat crop

\begin{tabular}{|c|c|c|c|}
\hline Treatments & $\begin{array}{c}\text { Grain yield } \\
\left.(\mathrm{q} \mathrm{ha})^{-1}\right)\end{array}$ & $\begin{array}{l}\text { Straw yield } \\
\left(\mathrm{q} \mathrm{ha}^{-1}\right)\end{array}$ & $\begin{array}{c}\text { Harvest index } \\
(\%) \\
\end{array}$ \\
\hline \multicolumn{4}{|l|}{ (A) Varieties } \\
\hline HD-2643 & 38.60 & 50.71 & 43.21 \\
\hline HUW-234 & 33.70 & 45.06 & 42.76 \\
\hline PBW-373 & 45.80 & 62.38 & 42.32 \\
\hline HD-2285 & 39.70 & 54.99 & 41.90 \\
\hline SEm \pm & 0.80 & 0.91 & 0.50 \\
\hline $\mathrm{CD}(\mathrm{P}=0.05)$ & 2.28 & 2.61 & NS \\
\hline \multicolumn{4}{|c|}{ (B) Nitrogen management practices } \\
\hline $90 \mathrm{~kg} \mathrm{~N} \mathrm{ha}^{-1}$ & 35.51 & 49.23 & 41.91 \\
\hline $120 \mathrm{~kg} \mathrm{~N} \mathrm{ha}^{-1}$ & 40.24 & 54.26 & 42.62 \\
\hline $\begin{array}{l}90 \mathrm{~kg} \mathrm{~N} \mathrm{ha}^{-1}+25 \% \mathrm{~N} \text { through } \\
\text { FYM }\end{array}$ & 38.66 & 52.97 & 42.21 \\
\hline $\begin{array}{l}120 \mathrm{~kg} \mathrm{~N} \mathrm{ha}{ }^{-1}+25 \% \mathrm{~N} \\
\text { through FYM }\end{array}$ & 41.03 & 54.69 & 42.89 \\
\hline $150 \mathrm{~kg} \mathrm{~N} \mathrm{ha}^{-1}$ & 41.82 & 55.27 & 43.09 \\
\hline SEm \pm & 0.89 & 1.02 & 0.55 \\
\hline $\mathrm{CD}(\mathrm{P}=0.05)$ & 2.55 & 2.67 & $\mathrm{NS}$ \\
\hline
\end{tabular}

\section{Straw yield $\left(\mathbf{q} \mathbf{h a}^{-1}\right)$}

The data presented in table 5 quite reveal that the straw yield was affected significantly due to varieties and nitrogen management practices. Among the varieties, maximum straw yield was recorded with variety PBW373, which significantly higher over all other varieties. Straw yield increased significantly with increasing levels of nitrogen upto $150 \mathrm{~kg}$ $\mathrm{N} \mathrm{ha}^{-1}$. Further increase in nitrogen levels up to did not bring significant increase in straw yield. Application of $150 \mathrm{~kg} \mathrm{~N}^{-1} \mathrm{ha}^{-1}$ recorded maximum straw yield which was at par with $120 \mathrm{~kg} \mathrm{~N} \mathrm{ha}^{-1}+25 \% \mathrm{~N}$ through FYM and 120 $\mathrm{kg} \mathrm{N} \mathrm{ha}{ }^{-1}$ and significantly superior over rest of the nitrogen management practices. Straw yield influenced significantly up to $150 \mathrm{~kg} \mathrm{~N}$ $\mathrm{ha}^{-1}$ (Table 5). This may be probably due to higher shoots and increased rate of dry matter accumulation. Similar results were given by Singh (2002).

\section{Harvest index (\%)}

Harvest index as influenced by various varieties and nitrogen management practices (Table 5). Harvest index indicate the relationship between economical yield and biological yield. The data reveals that varieties and nitrogen management practices not influenced significantly. The maximum harvest index (5) was recorded with varieties HD 2643 and it was recorded minimum (41.90) with variety HD 2285 during experimentation. Regarding nitrogen management practices it was highest (43.09) with $150 \mathrm{~kg} \mathrm{~N} \mathrm{ha}^{-1}$ and minimum (41.90) with $90 \mathrm{~kg} \mathrm{~N} \mathrm{ha}^{-1}$. Harvest index of wheat was not affected significantly due to nitrogen management practices (Table 5). Similar results were given by Singh (1998). The highest grain and straw yield was recorded with variety PBW-373 followed by variety HD-2285 (Table 5). The reason behind this 
may be because of good plant stand, more number of ear bearing tillers, long ear head and more number of grains ear ${ }^{-1}$ with more test weight. Minimum grain yield recorded with variety HUW-234, might be due to less number of ear bearing tillers, small ear head and less number of grains ear ${ }^{-1}$ and poor grain development. Similar findings were obtained by Singh (1998) and Sardana et al., (1999). The varieties did not differ significantly in harvest index.

\section{References}

Anonymous. 2013. The Hindu Survey of Indian Agriculture. Printed \& Published at the National Press, Chennai.

Avijit, S., Pandey, M.D., Sharma, S.N., Singh, R.K., Kumar, A., Prakash, S., Srivastava, V.K. and Shukla, P. 2003. Surface seeding of wheat (Triticum aestivum L.) as affected by seed rate and nitrogen level. Indian $J$. Agril. Sci., 73(9): 509-511.

Behra, A.K. 1994. Response of wheat (Triticum aestivum L.) varieties to date of sowing. Indian J. Agron., 31(1): 171-173.

Brijkishor. 1998. To assess the performance of newly developed strains of wheat under zero tillage condition with varying nitrogen levels. M.Sc. Ag.) Thesis submitted to N.D.U.A \& T., Kumarganj, Faizabad.

Gontia, A.S. and Joshi, A. 2000. Effect of varying population densities and nitrogen levels on yield and yield attributes of wheat. Crop Res., 19(2): 184-188.

Kumpawat, B.S. and Rathore S.S. 2003. Effect of preceding grain legumes on growth, yield, nutrient content and uptake by wheat (Triticum aestivum L.) under different nitrogen levels. Crop-research-Hisar, 25(2): 209-214.
Liaquat-Ali, Qamar- Mohy-ud-Din and MushtoqAli. 2003. Effect of different doses of nitrogen fertilizer on the yield of wheat. Int. J. Agrl. Biol., 5(4): 438-439.

Mankotia, K., Savic, N., Jelic, J. and Nikoic, K. 2007. The influence of mineral nitrogen on plant height and spike length at various cultivars of winter wheat. Faculty of agriculture, University of Prishtin, Lesak, Serbia. 58(2): 37-42.

Parihar, S.S. 2004. Effect of crop-establishment methods, tillage, irrigation and nitrogen on production potential of Rice (Oryza sativa)Wheat (Triticum aestivum L.) cropping system. Indian J. Agron., 49(1): 1-5.

Ram Tulsa and MIR, M.S. 2006. Effect of irrigated nutrient management on yield and yield attributing characters of wheat (Triticum aestivum L). Indian J. Agron. 51(3): 189-192.

Sardana, V., Sharma, S.K. and Randhawa, A.S. 1999. Performance of wheat cultivars under different sowing dates and levels of nitrogen under rainfed conditions. Ann. Agri. Res., 20(1): 60-63.

Singh, A.N. 2002. Response of wheat varieties to various nitrogen levels. M.Sc. Ag. b) thesis submitted to NDUA\&T, Kumarganj, Faizabad, (U.P.), India.

Singh, B. 1998. To assess the performance of new wheat varieties under late-sown condition with different nitrogen levels. M.Sc.(Ag) thesis submitted to N.D.U.A.\&T., Kumarganj, Faizabad

Subbiah, B.V. and Bajaj, J.C. 1968. Association of certain soil factors with higher paddy yields. J. Indian Soc. Soil Sci., 16(3): 297300 .

White, R.O. 1957. The grassland and fodder resources in India. Scientific monograph, no. 22, ICAR: 1-47.

\section{How to cite this article:}

Shiv Vendra Singh, Avanish Kumar Singh, Nikhil Raghuvanshi and Singh, R.A. 2017. Effect of Nitrogen Management Practices on the Productivity of Late Sown Wheat (Triticum aestivum L.) Varieties. Int.J.Curr.Microbiol.App.Sci. 6(7): 878-887.

doi: https://doi.org/10.20546/ijcmas.2017.607.108 